\title{
Erratum to: 'The orientation of transcription factor binding site motifs in gene promoter regions: does it matter?'
}

Monika Lis and Dirk Walther

Unfortunately, the original version of this article [1] contained an error. Equation number two was missing a "-" (a minus) sign before the sum symbol. The correct equation has been included here. This correction concerns the notation only. All computations using this equation were done correctly.

$$
P E_{m}=-\sum_{i} p_{i} \log \left(p_{i}\right)
$$

Received: 18 April 2016 Accepted: 18 April 2016

Published online: 28 April 2016

\section{Reference}

1. Lis $M$, Walther $D$. The orientation of transcription factor binding site motifs in gene promoter regions: does it matter? BMC Genomics. 2016;17:185.

Submit your next manuscript to BioMed Central and we will help you at every step:

- We accept pre-submission inquiries

- Our selector tool helps you to find the most relevant journal

- We provide round the clock customer support

- Convenient online submission

- Thorough peer review

- Inclusion in PubMed and all major indexing services

- Maximum visibility for your research

Submit your manuscript at www.biomedcentral.com/submit
() Biomed Central 